\author{
A.R. Yeshkeyev, A.K. Issaeva, N.M. Mussina \\ Ye.A. Buketov Karaganda State University, Kazakhstan \\ (E-mail: nazerke170493@mail.ru)
}

\title{
The atomic definable subsets of semantic model
}

\begin{abstract}
In this paper some properties of small models, generally speaking, not necessarily complete theories and their relationship with each other were considered. Under small models we will understand some modifications of the concepts of countable atomic and prime models. These models were defined in the study of countable models of complete theories. Studies were conducted by analogy with the classic result of R. Vaught on countable-prime models of complete theories, but by other technical means. This work is oriented on the syntactic properties of special subsets of the semantic model of some Jonsson theory. A new concept was also introduced, as a model-theoretic «rheostat», in order to obtain results related to the refinement of concept of atomicity within the framework of Jonsson theories. Thus, the main purpose of this article is to formally define this «rheostat» and to obtain on the basis of this concept the results having a relation to the refinement of the concept of atomicity in the frame of Jonsson theories.
\end{abstract}

Keywords: Jonsson theory, semantic model, existentially prime model, atomic model, convexity.

The study of properties of the so-called small models for various subclasses of inductive theories is connecting with given work. Each time the difference in these subclasses always depends on the special conditions imposed on some inductive theory. These conditions are of the following type: the joint embedding property, the amalgam property, convexity, an existential primeness, a certain type of completeness, perfectness in the sense of Jonsson theory, if the considered inductive theory is such. All of these conditions are connected with considered theory, but are not purely syntactic, since the above mentioned definitions of conditions relate to the class of models of considered theory, for example, convexity and an existential primeness. On the other hand, the main accent of this work is oriented on the syntactic properties of special subsets of the semantic model of some Jonsson theory.

We consider small models which are some modifications of the concepts of countable atomic and prime models defined in the study of countable models of complete theories. This subject was originally defined after R. Vaught's classical work [1] where it was proved that a model is atomic if and only if it is countable and prime. In [2] D. Baldwin and D. Kueker considered a more general situation in the sense of theory and in the sense of small models.

Namely, the theory was assumed only complete for some type of sentences, i.e. generally speaking, not the complete and the concepts of atomicity and primeness of model, in contrast to the concept of atomicity and primeness of the model from [1], were also more general because the atoms of a theory were considered within the formulas lattice and not the Boolean algebra of the Lindenbaum-Tarsky. Also, instead of elementary embeddings, isomorphic embeddings were considered. Further, we give these definitions and consider in detail their differences.

As the results of [2] showed, unfortunately, it was not possible to obtain, analogue of the above mentioned, the result describing a small models from [1]. Thus, the study of the behavior of the small models in the class of incomplete theories is an actual problem and in general it has not been solved yet. Moreover, due to the examples in [2], there is a confidence that this problem will not be solved in the formulated framework of [2]. In this regard, one of the authors of this article in [3-6] formulated the problem of characterization of countable atomic and prime models in the study of Jonsson theories, its class, first of all, is a natural subclass of inductive theories, secondly, there are a lot of classical natural examples from algebra which satisfy the conditions of Jonsson theories. Thus, it seems to us it is possible to narrow down the scope of the above mentioned problem, both in the syntactic and semantic sense in fairly wide subclass of inductive theories to advance a search for a positive solution of this problem. It is necessary to find acceptable conditions that connect corresponding concepts of atomicity and algebraic primeness of models in the framework of studying the data restrictions on the theory. 
In this introduction we would like to announce the main idea of our approach to the study of the description of small models within the above-mentioned. Since, by virtue of the above concepts of the atomic model, in senses of [1] and [2], there are essentially different, we propose to consider in a certain sense a «continuous» transition from the notion of model atomicity in the sense of [1] to the notion of model atomicity in the sense of [2]. Thus, we tried gradually to isolate the metamorphosis of the transition of these concepts into each other in stages. That is, to construct conditionally in a certain sense a model-theoretic «rheostat» by moving, we get the concepts of atomicity for complete and Jonsson theories, gradually. Thus, the main purpose of this article is formally to define this «rheostat» and to obtain, on the basis of this concept, results concerning to the refinement of the concept of atomicity within of Jonsson theories.

We give the following definitions of concepts and related results from that part of model theory that are necessary for the study of Jonsson theories.

Definition 1. A theory $T$ is a Jonsson if:

1) theory $T$ has infinite models;

2) theory $T$ is inductive;

3 ) theory $T$ has the joint embedding property $(J E P)$;

4 ) theory $T$ has the property of amalgam $(A P)$.

Examples of Jonsson theories are:

1) the group Theory,

2) the theory of Abelian groups,

3) the theory of fields of fixed characteristic,

4) the theory of Boolean algebras,

5) the theory of polygons over a fixed monoid,

6) the theory of modules over a fixed ring,

7) the theory of linear order.

The following definition of the universality and homogeneity of model allocates semantic invariant of any Jonsson theory, namely its semantic model. Moreover, it turned out that the saturation or non-saturation of this model significantly changes the structural properties of both the Jonsson theory itself and its class of models.

Definition 2. Let $\kappa \geq \omega$. Model $M$ of theory $T$ is said to be $\kappa$-universal for $T$, if each model $T$ with the power strictly less $\kappa$ isomorphically imbedded in $M ; \kappa$-homogeneous for $T$, if for any two models $A$ and $A_{1}$ of theory $T$, which are submodels of $M$ with the power strictly less then $\kappa$ and for isomorphism $f: A \rightarrow A_{1}$ for each extension $B$ of model $A$, which is a submodel of $M$ and is model of $T$ with the power strictly less then $\kappa$ there exists the extension $B_{1}$ of model $A_{1}$, which is a submodel of $M$ and an isomorphism $g: B \rightarrow B_{1}$ which extends $f$.

Definition 3. Model $C$ of Jonsson theory $T$ is said to be semantic model, if it is $\omega^{+}$- homogeneous-universal.

As can be seen from the definition of the Jonsson theory, this theory is not complete. But nevertheless, with the help of its semantic invariant (semantic model) we can always determine the center of Jonsson theory, which is a complete theory.

Definition 4. The center of Jonsson theory $T$ is said to be an elementary theory of its semantic model. And denoted through $T^{*}$, i.e. $T^{*}=T h(C)$.

The following two facts speak about the «good» exclusivity of the semantic model.

Fact 1. Each Jonsson theory $T$ has $k^{+}$- homogeneous-universal model of power $2^{k}$. Conversely, if a theory $T$ is inductive and has infinite model and $\omega^{+}$- homogeneous-universal model then the theory $T$ is a Jonsson theory.

Fact 2. Let $T$ be a Jonsson theory. Two $k$-homogeneous-universal models $M$ and $M_{1}$ of $T$ are elementary equivalent.

It is well known from the course of model theory that a saturated model is always a homogeneous-universal model, the reverse is also true. But this definition of homogeneous-universal model [7; 299] is considered as a rule in the framework in the study of complete theory. In the framework of the study of Jonsson theory, we are dealing with a particular case of the definition of a homogeneous-universal model belonging to B. Jonsson [8]. The concept of a saturated model is the same in both cases. By virtue of a more general situation of homogeneousuniversality in the case of Jonsson theory, we do not have a saturation criterion in terms of homogeneousuniversal as in $[7 ; 299]$. Therefore, those Jonsson theories, the semantic model of which is saturated, allocate in a special subclass of class of all Jonsson theories, and such theories are called perfect. We give a definition of perfectness of Jonsson theory. 
Definition 5. Jonsson theory $T$ is said to be a perfect theory, if each semantic model of theory $T$ is saturated model of $T^{*}$.

The first author of this article obtained a result describing the perfect Jonsson theory.

Theorem 1 [9]. Let $T$ be a Jonsson theory. Then the following conditions are equivalent:

1) Theory $T$ is perfect;

2) Theory $T^{*}$ is a model companion of theory $T$.

From the above list of Jonsson theories, the following examples 2)-4), 6),7) are examples of a perfect Jonsson theory. But, for example, group theory is not such, due to the fact that it does not have a model companion.

Let $E_{T}$ be a class of all existentially closed models of Jonsson theory $T$.

This class of models in general case for an arbitrary theory can be empty. But the following result [10; 367] is well known, who says that any inductive theory has a nonempty class of existentially closed models. Since the Jonsson theory is a subclass of the class of inductive theories, we can say that $E_{T}$ is a non-empty class.

In the case of a perfect Jonsson theory, the class of models of center of this theory coincides with $E_{T}$. This follows from the following theorem.

Theorem 2 [9]. If $T$ is a perfect Jonsson theory then $E_{T}=\operatorname{Mod} T^{*}$.

Let $L$ be a countable language of first order. Let $T$ be Jonsson theory in the language $L$ and its semantic model is $C$.

Let us turn to the definition of central concept of this article. Namely, the concept of a $\left(\nabla_{1}, \nabla_{2}\right)-c l$ atomic set.

Let $T$ be some Jonsson theory in a fixed language and $C$ - its semantic model.

Definition 6 . Model $A$ of a theory $T$ is said to be existentially closed if for any model $B$ and any existential formula $\varphi(\bar{x})$ with constants of $A$ we have $A \models \exists \bar{x} \varphi(\bar{x})$ provided that $A$ is a submodel of $B$ and $B \models \exists \bar{x} \varphi(\bar{x})$.

Definition 7. $A$ is an algebraically prime model of theory $T$, if $A$ is a model of $T$ and $A$ may be isomorphically embedded in each model of the theory $T$.

Definition 8 . The inductive theory $T$ is said to be the existentially prime if: 1 ) it has an algebraically prime model, the class of its $A P$ (algebraically prime models) denote by $A P_{T} ; 2$ ) class $E_{T}$ non trivial intersects with class $A P_{T}$, i.e. $A P_{T} \cap E_{T} \neq 0$.

Definition 9. The theory $T$ is said to be convex if for any its model $A$ and for any family $\left\{B_{i} \mid i \in I\right\}$ of substructures of $A$, which are models of the theory $T$, the intersection $\bigcap_{i \in I} B_{i}$ is a model of $T$, provided it is non-empty. If in addition such an intersection is never empty, then $T$ is said to be strongly convex.

Definition 10. A model is said to be atomic if every tuple of its elements satisfies some complete formula.

Definition 11. A formula $\varphi(\bar{x})$ is a $\Delta$-formula, if exist existential formulas (from $\Sigma) \psi_{1}(\bar{x})$ and $\psi_{2}(\bar{x})$ such as

$$
T \models\left(\varphi \leftrightarrow \psi_{1}\right) \quad \text { и } \quad T \models\left(\neg \varphi \leftrightarrow \psi_{2}\right) .
$$

Definition 12.

(i) $\left(A, a_{0}, \ldots, a_{n-1}\right) \Rightarrow_{\Gamma}\left(B, b_{0}, \ldots, b_{n-1}\right)$ means that for every formula $\varphi\left(x_{1}, \ldots, x_{n-1}\right)$ of $\Gamma$, if $A \models \varphi(\bar{a})$, then $B \models \varphi(\bar{b})$.

(ii) $(A, \bar{a}) \equiv_{\Gamma}(B, \bar{b})$ means that $(A, \bar{a}) \Rightarrow_{\Gamma}(B, \bar{b})$ and $(B, \bar{b}) \Rightarrow_{\Gamma}(A, \bar{a})$.

As classes $\Gamma$ we consider $\triangle$ or $\Sigma$.

The following definition of an atomic model refers to [1].

Consider a complete theory $T$ in $L$. A formula $\varphi\left(x_{1} \ldots x_{n}\right)$ is said to be complete (in $T$ ) if and only if for every formula $\psi\left(x_{1} \ldots x_{n}\right)$ exactly one of

$$
T \models \varphi \rightarrow \psi, \quad T \models \varphi \rightarrow \neg \psi
$$

holds. A formula $\theta\left(x_{1} \ldots x_{n}\right)$ is said to be completable (in $T$ ) if and only if there is a complete formula $\varphi\left(x_{1} \ldots x_{n}\right)$ with $T \models \varphi \rightarrow \theta$. If $\theta\left(x_{1} \ldots x_{n}\right)$ is not completable it is said to be incompleatable.

A theory $T$ is said to be atomic if and only if every formula of $L$ which is consistent with $T$ is completable in $T$. A model $A$ is said to be an atomic model if and only if every $n$ - tuple $a_{1} \ldots a_{n} \in A$ satisfies a complete formula in $T h(A)$.

Definition 13. A model is said to be atomic if every tuple of its elements satisfies some complete formula. In connection with the new concept of atomicity from [2], the following concept will be analogous to the definition of a complete formula. 
Definition 14. A formula $\varphi\left(x_{1}, \ldots, x_{n}\right)$ is complete for $\Gamma$-formulas(w.r.t $\mathrm{T}$ ) if $\varphi$ is consistent with $T$ and for every formula $\psi\left(x_{1}, \ldots, x_{n}\right)$ in $\Gamma$, having no more free variables than $\varphi$, either

\section{$T=\forall \bar{x}(\varphi \rightarrow \psi)$ or $T \vDash \forall \bar{x}(\varphi \rightarrow \neg \psi)$.}

Equivalently, a consistent $\varphi(\bar{x})$ is complete for $\Gamma$-formulas provided whenever as $\psi(\bar{x})$ is a $\Gamma$-formula and $(\varphi \wedge \psi)$ is consistent with $T$, then $T \models(\varphi \rightarrow \psi)$.

And the concept of the atomic model from [1] is transformed into the following concept from [2].

Definition 15. $B$ is a $\left(\Gamma_{1}, \Gamma_{2},\right)$ - atomic model of $T$, if $B$ is a model of $T$ and for every $n$ every $n$-tuple of elements of $A$ satisfies some formula from $B$ in $\Gamma_{1}$, which is complete for $\Gamma_{2}$-formulas.

The following notion of a weakly atomic model from [2] is a generalization of above definition.

Definition 16. $B$ is a weak $\left(\Gamma_{1}, \Gamma_{2}\right)$ - atomic model of $T$, if $B$ is a model of $T$ and for every $n$ every $n$-tuple $\bar{a}$ a of elements of $A$ satisfies in $B$ some formula $\varphi(\bar{x})$ of $\Gamma_{1}$ such as $T \models(\varphi \rightarrow \psi)$ as soon as $\psi(\bar{x})$ of $\Gamma_{2}$ and $B \models \psi(\bar{a})$.

In this paper we will not give examples of the $\left(\Gamma_{1}, \Gamma_{2}\right)$ - atomic model and the weak $\left(\Gamma_{1}, \Gamma_{2}\right)$ atomic model, leaving the reader to do this on their own, referring to a sufficient, the number of examples of these concepts given in [2].

Before discussing the obtained results, concerning to $\left(\nabla_{1}, \nabla_{2}\right)-c l$ atomic models, we note that we fix some Jonsson theory $T$ and its semantic model $C$ in the countable language $L$ and $\nabla_{1}, \nabla_{2} \subseteq L:\left(\nabla_{1}, \nabla_{2}\right)$ actually those sets consist of $\exists, \forall, \forall \exists$ - formulas which are consistent with $T$, that is, any finite subset of formulas from $\nabla_{1}, \nabla_{2}$ are consistent with $T$. Let $A \subseteq C$.

Let $c l$ is some closure operator defining a pregeometry over $C$ (for example $c l=a c l$ or $c l=d c l$ ). It is clear that such operator is a special case of the closure operator and its example is a closure operator defined on any linear space as a linear shell.

We also assume that the pregeometry given by the $c l$ operator is modular [8].

Definition 17. A set $A$ is said to be $\left(\nabla_{1}, \nabla_{2}\right)-c l$ atomic in the theory $T$, if

1) $\forall a \in A, \exists \varphi \in \nabla_{1}$ such as for any formula $\psi \in \nabla_{2}$ follows that $\varphi$ is complete formula for $\psi$ and $C \models \varphi(a)$;

2) $\operatorname{cl}(A)=M, M \in E_{T}$, and obtained model $M$ is said to be $\left(\nabla_{1}, \nabla_{2}\right)-c l$ atomic model of theory $T$.

Definition 18. A set $A$ is said to be weakly $\left(\nabla_{1}, \nabla_{2}\right)-c l$ is atomic in $T$, if

1) $\forall a \in A, \exists \varphi \in \nabla_{1}$ such as in $C \models \varphi(a)$ for any formula $\psi \in \nabla_{2}$ follows that $T \models(\varphi \rightarrow \psi)$ whenever $\psi(x)$ of $\nabla_{2}$ and $C \models \psi(a)$;

2) $\operatorname{cl}(A)=M, M \in E_{T}$, and obtained model $M$ is said to be weakly $\left(\nabla_{1}, \nabla_{2}\right)-c l$ atomic model of theory $T$.

It is easy to understand that definitions 17 and 18 are naturally generalized the notion of atomicity and weak atomicity to be $\nabla_{1}$-atom and weak $\nabla_{1}$-atom for any tuple of finite length from set $A$.

Let $i \in\{1,2\}, M_{i}=c l\left(A_{i}\right)$, where $A_{i}=\left(\nabla_{1}, \nabla_{2}\right)$ is a $c l-$ atomic set $. a_{0}, \ldots, a_{n-1} \in A_{1}, b_{0}, \ldots, b_{n-1} \in A_{2}$.

Definition 19.

(i) $\left(M_{1}, a_{0}, \ldots, a_{n-1}\right) \Rightarrow_{\nabla}\left(M_{2}, b_{0}, \ldots, b_{n-1}\right)$ means that for every formula $\varphi\left(x_{1}, \ldots, x_{n-1}\right)$ of $\nabla$, if $M_{1} \models \varphi(\bar{a})$, then $M_{2} \models \varphi(\bar{b})$.

(ii) $\left(M_{1}, \bar{a}\right) \equiv_{\nabla}\left(M_{2}, \bar{b}\right)$ means that $\left(M_{1}, \bar{a}\right) \Rightarrow_{\nabla}\left(M_{2}, \bar{b}\right)$ and $\left(M_{1}, \bar{b}\right) \Rightarrow_{\nabla}\left(M_{1}, \bar{a}\right)$.

Definition 20. A set $A$ is said to be $\left(\nabla_{1}, \nabla_{2}\right)-c$-algebraically prime in the theory $T$, if

1) If $A$ is $\left(\nabla_{1}, \nabla_{2}\right)-c l$-atomic set in $T$;

2) $\operatorname{cl}(A)=M, M \in A P_{T}$, and obtained model $M$ is said to be $\left(\nabla_{1}, \nabla_{2}\right)-c l$ algebraically prime model of theory $T$.

From the definition of an algebraically prime set in the theory $T$ follows that the Jonsson theory $T$ which has an algebraically prime set is automatically existentially prime. It is easy to understand that an example of such a theory is the theory of linear spaces.

Definition 21. The set $A$ is said to be $\left(\nabla_{1}, \nabla_{2}\right)-c l$-core in the theory $T$, if

1) $A$ is $\left(\nabla_{1}, \nabla_{2}\right)$ a $c l$ - atomic set in the theory $T$;

2) $\operatorname{cl}(A)=M$, and obtained model $M$ is said to be $\left(\nabla_{1}, \nabla_{2}\right)-c l$ core model of theory $T$.

Definition 22. (a) A - $\left(\nabla_{1}, \nabla_{2}\right)-c l$-atomic set in theory $T$ is said to be A $-\left(\nabla_{1}, \nabla_{2}\right)-c l$ - $\Sigma$-nice-set in theory $T, \forall A^{\prime}: A^{\prime}-\left(\nabla_{1}, \nabla_{2}\right)-c l$-atomic set in theory $T$, if

1) $\operatorname{cl}(A)=M \in E_{T} \cap A P_{T}$, and obtained model $M$ is said to be $\left(\nabla_{1}, \nabla_{2}\right)-c l$ - $\Sigma$-nice model of theory $T$.

2) for all $a_{0}, \ldots, a_{n-1} \in A, b_{0}, \ldots, b_{n-1} \in A^{\prime}$, if $\left(M, a_{0}, \ldots, a_{n-1}\right) \Rightarrow_{\exists}\left(M^{\prime}, b_{0}, \ldots, b_{n-1}\right)$, then $\forall a_{n} \in A, \exists b_{n} \in A^{\prime}$ such as $\left(M, a_{0}, \ldots, a_{n}\right) \Rightarrow_{\exists}\left(M^{\prime}, b_{0}, \ldots, b_{n}\right)$, where $M^{\prime}=c l\left(A^{\prime}\right)$. 
(b) $A-\left(\nabla_{1}, \nabla_{2}\right)-c l-\Sigma^{*}$ - nice-set in theory $T$ if the condition in (a) holds with ' $\Rightarrow \exists$ ' replaced both places it occurs by ' $\equiv_{\exists}$ '

and obtained model $M$ is said to be $\left(\nabla_{1}, \nabla_{2}\right)-c l$ - $\Sigma^{*}$ - nice model of theory $T$.

(c) $A-\left(\nabla_{1}, \nabla_{2}\right)-c l-\Delta$ - nice-set in theory $T$ if the condition in (a) holds with ' $\Rightarrow{ }_{\Delta}$ ' replaced both places it occurs by ' $\equiv_{\Delta}$ ', where $\Delta \subseteq L, \Delta=\forall \cap \exists$.

and obtained model $M$ is said to be $\left(\nabla_{1}, \nabla_{2}\right)-c l-\Delta$-nice model of theory $T$.

Principle of «rheostat».

Let two countable models $A_{1}, A_{2}$ of some Jonsson theory $T$ be given. Moreover, $A_{1}$ is an atomic model in the sense of [1], and $X$ is $\left(\nabla_{1}, \nabla_{2}\right)-c l$-algebraically prime set of theory $T$ and $c l(X)=A_{2}$. Since $\nabla_{1}=\nabla_{2}=L$, then $A_{1} \cong A_{2}$.

By the definition of $\left(\nabla_{1}, \nabla_{2}\right)$ - algebraic primeness of the set $X$, the model $A_{2}$ is both existentially closed and algebraically prime. Thus, the model $A_{2}$ is isomorphically embedded in the model $A_{1}$. If by condition the model $A_{1}$ is countably atomic, then according to the Vaught's theorem, $A_{1}$ is prime, i.e. it is elementarily embedded in the model $A_{2}$. Thus, the models $A_{1}, A_{2}$ differ from each other only by the interior of the set $X$. This follows from the fact that any element of $a \in A_{2} \backslash X$ implements some principal type, since $a \in \operatorname{cl}(X)$. That is, all countable atomic models in the sense of [1] are isomorphic to each other, then by increasing $X$ we find more elements that do not realize the principal type and, accordingly, $\operatorname{cl}(X)$ is not an atomic model in the sense of [1]. Thus, the principle of rheostat is that, by increasing the power of the set $X$, we move away from the notion of atomicity in the sense of [1] and on the contrary, decreasing the power of the set $X$ we move away from the notion of atomicity in the sense of [2].

Let $A P C \in$ atomic, algebraically prime, core $\}$. Thus, by specifying the set $X$ as $\left(\nabla_{1}, \nabla_{2}\right)-$ $c l-A P C$, (where $A P C$ is a semantic property), we can also specify atomicity in the sense [2] in relation to atomicity in the sense of [1]. And according to the usage using of the principle of «rheostat» after the $A P C$ property is defined, we obtain the corresponding concepts of atomic models, the role of which is played by $A_{2}$ from the principle of «rheostat».

Two authors of this article have got the following result which connected with this topic and this result will publish in near future.

Theorem 1. Let $T$ be complete for $\exists$-sentences, a strongly convex Jonsson perfect theory and let $A$ is $\left(\nabla_{1}, \nabla_{2}\right)-c l$-atomic set in $T$.

Then $(i) \Rightarrow(i i) \Rightarrow(i i i) \Rightarrow(i v) \wedge(v i),(i) \Rightarrow(i)^{*} \Rightarrow(v) \Rightarrow(v i),(i i) \Rightarrow(i i)^{*} \Rightarrow(v i),(i)^{*} \Rightarrow(i i)^{*}$ and $(i v)^{*} \Rightarrow(i v)$, where:

(i) $A$ is $(\Delta, \Sigma)-c l$-atomic set in theory $T$,

$(i)^{*} A$ is weakly $(\Delta, \Pi)-c l$-atomic set in theory $T$,

(ii) $A$ is $(\Sigma, \Sigma)-c l$-atomic set in theory $T$,

(ii)* $A$ is weakly $(\Sigma, \Pi)-c l$-atomic set in theory $T$,

(iii) $A$ is weakly $(\Sigma, \Sigma)-c l$-atomic set in theory $T$,

(iv) $\operatorname{cl}(A) \in A P_{T}$,

(iv)* $A$ is core set in theory $T$,

(v) $A$ is weakly $(\Delta, \Delta)-c l$-atomic set in theory $T$,

(vi) $A$ is weakly $(\Sigma, \Delta)-c l$-atomic set in theory $T$.

In according to the above mentioned notions, we have the following theorems. Those results are very close to investigation around atomicity and algebraically primeness in the frame of [2]. Nevertheless even if algebraically primeness is the same, but the combinations of $A P C$-atomicity differ from atomicity from [2].

Theorem 2. Let $T$ be complete for $\exists$-sentences, a strongly convex Jonsson perfect theory and let $M$ is $\left(\nabla_{1}, \nabla_{2}\right)-c l$-atomic model in $T$.

(a) Then $(i) \Rightarrow(i i) \Rightarrow(i i i) \Rightarrow(i v) \Rightarrow(v i),(i) \Rightarrow(i)^{*} \Rightarrow(v) \Rightarrow(v i),(i i) \Rightarrow(i i)^{*} \Rightarrow(v i)$, and $(i)^{*} \Rightarrow(i i)^{*}$ and $(i v)^{*} \Rightarrow(i v)$, where:

(i) $M$ is $(\Delta, \Sigma)-c l$-atomic model in theory $T$,

(i) ${ }^{*} M$ is a weakly $(\Delta, \Pi)-c l$-atomic model in theory $T$

(ii) $M$ is a $(\Sigma, \Sigma)-c l$-atomic model in theory $T$,

$(i i)^{*} M$ is a weakly $(\Sigma, \Pi)-c l$-atomic model in theory $T$,

(iii) $M$ is a weakly $(\Sigma, \Sigma)-c l$-atomic model in theory $T$,

(iv) $M \in A P_{T}$,

$(i v)^{*} M$ is core model in theory $T$,

$(v) M$ is $(\Delta, \Delta)-c l$-atomic model in theory $T$, 
(vi) $M$ is $(\Sigma, \Delta)-c l$-atomic model in theory $T$,

(b) If $T$ is complete for $\forall \exists$ sentences, then $(i) \Leftrightarrow(i)^{*}$ and $(i i) \Leftrightarrow(i i)^{*}$.

Proof. We have to note that for us sufficiently work with the $(\Sigma, \Sigma)-c l$-atomic set, i.e. the elements from outside of this set in any type of atomic model of this theory will realize the principal type and this fact allowed say for us that such element belongs to any type of atomic model. It is sufficient to get that existence of any kind of atomic model in our meaning following from fact that a given theory has countable atomic models of any type of it. Therefore, all parts of this Theorem are immediate from Theorem 1 and the existence of such sets admit for us corresponding type of atomicity. We have only one exception: that is the implication $(i v) \Rightarrow(v i)$. So, assume that $T$ has an algebraically prime model $B$. Let $\bar{b}_{n} \in B$ and let $\left\{\psi_{i}(\bar{x}): i \in \omega\right\}$ list all the $\Delta$-formulas satisfied by $\bar{b}$ in $B$. Since $B$ is a.p. we know there is no model of $T$ satisfying $\forall \bar{x} \bigvee_{i} \neg \psi_{i}$. Since $\neg \psi_{i}$ is existential we can apply above pointed Theorem 1 to get an existential formula $\psi(\bar{x})$ consistent with $T$ such as $T \models\left(\psi \rightarrow \psi_{i}\right)$ for all $i \in \omega$. This $\psi$ is hence complete for $\Delta$-formulas, and also implies any open formula satisfied by $\bar{a}$ in $A$. Every open formula consistent with $T$ is satisfied by some $a_{0}, \ldots, a_{n} \in A$, and therefore is implied by some existential formula complete for $\Delta$-formulas. In the connections with the fact that we obtained $(\Sigma, \Sigma)-c l$-algebraically prime model in theory $T$ we can apply Theorem 2.2 from [2] (iii) in order to show that $T$ has a $(\Sigma, \Delta)-c l$-atomic model.

Lemma 1 [11]. Let $T$ be complete for existential sentences perfect Jonsson theory.

1) If $A$ is weakly $(\nabla, \Delta)-c l$-atomic set in the theory $T$, then $A$ is $(\nabla, \Delta)-c l$-atomic set,

2) If $A$ is weak $(\nabla, \Delta)-c l$-atomic set in the theory $T$, then $A$ is $(\nabla, \Delta)-c l$-atomic set.

Before we will prove the theorem 2 let us note the following Remark.

Remark 1 [11]. By the perfectness of $T$, we can apply Lemma 1 and then, by Lemma 1 , we can replace $\nabla_{i}$ on $\Delta$, where $i \in\{1,2\}$. Due to the strongly convexity of the theory, the theory $T$ has a unique core model. This follows from the fact that if the theory satisfies the property of joint embedding and is additionally strongly convex, then its core model in the theory $T$ is unique up to isomorphism [7]. Based on this fact, we can conclude that under the conditions of this theorem we have a unique core model, since its existence follows from strongly convexity, and its uniqueness follows from the combination with Jonssonness.

Theorem 3. Let $T$ be complete for $\exists$-sentences a strongly convex Jonsson perfect theory and let $M$ is $\left(\nabla_{1}, \nabla_{2}\right)-c l$-atomic model in $T$.

(a) Then $(i) \Rightarrow(i i) \Rightarrow(i i i)$ and $(i i) \Rightarrow(i i)^{*}$ where:

(i) $M$ is $(\Sigma, \Sigma)-c l$-atomic model in theory $T$,

(ii) $M$ is $\left(\nabla_{1}, \nabla_{2}\right)-c l$ - $\Sigma^{*}$-nice-model in theory $T$,

$(\text { ii })^{*} M$ is e.c. and $\left(\nabla_{1}, \nabla_{2}\right)-c l$ - $\Sigma$-nice-model in theory $T$,

(iii) $M$ is weak $(\Sigma, \Pi)-c l$-atomic model in theory $T$,

(b) If $T$ is complete for $\forall \exists$ sentences, then $(i),(i i),(i i)^{*}$ and (iii) are all equivalent.

Proof. Easy to note that proof of this theorem follows from Theorem 1, Theorem 2, Remark 1 and Theorem 3.2 from [2].

From above results of Theorem 2 and Theorem 3 we can conclude that the mechanism of «rheostat» for atomicity behave regard itself very predictable: if more of elements from $\left(\nabla_{1}, \nabla_{2}\right)-c l$-atomic set inside in an atomic model by meaning of [1] we obtain more far property of atomicity from [1] and more close to atomicity from [2].

All concepts, that are not defined here, can be extracted from $[9,11]$.

\section{References}

1 Vaught R. Denumerable models of complete theories in Infinitistic Methode / R. Vaught // Pergamon. London, 1961. - P. 303-321.

2 Baldwin J.T. Algebraically prime models / J.T. Baldwin, D.W. Kueker // Ann. Math. Logic. - 1981. 20. - P. 289-330.

3 Yeshkeyev A.R. Strongly minimal Jonsson sets and their properties / A.R. Yeshkeyev // Bulletin of the Karaganda University. Mathematics series. - 2015. - Vol. 80, No. 4. - P. 47-51.

4 Poizat B. Positive Jonsson Theories / B. Poizat, A.R. Yeshkeyev // Logica Universalis. - 2018. - Vol. 12, No. 1-2. - P. 101-127. 
5 Yeshkeyev A.R. Properties of lattices of the existential formulas of Jonsson fragments / A.R. Yeshkeyev, M.T. Kasymetova // Bulletin of the Karaganda University. Mathematics series. - 2015. — Vol. 79, No. 3. - P. 25-32.

6 Yeshkeyev A.R. On lattice of existential formulas for fragment of Jonsson set / A.R. Yeshkeyev, O.I. Ulbrikht // Bulletin of the Karaganda University. Mathematics series. - 2015. - Vol. 79, No. 3. - P. 33-39.

7 Кейслер Х.Дж. Теория моделей / Х.Дж. Кейслер , Ч.Ч. Чэн. - М.: Мир, 1977. - 614 с.

8 Jonsson B. Homogeneous universal relational systems / B. Jonsson. - Math. Scand, 1960. - P. $137-142$.

9 Ешкеев А.Р. Йонсоновские теории и их классы моделей: моногр. / А.Р. Ешкеев, М.Т. Касыметова. - Караганда: Изд-во КарГУ, 2016. - 370 с.

10 Hodges W.A. Model Theory / W.A. Hodges. - Cambridge University Press, 1993. - P. 772.

11 Yeshkeyev A.R. $\nabla$-cl-atomic and prime sets / Yeshkeyev A.R., Issayeva A.K. // Bulletin of the Karaganda University. Mathematics series. - 2019. - Vol. 93, No. 1. - P. 88-94.

\title{
А.Р. Ешкеев, А.Қ. Исаева, Н.М. Мусина
}

\section{Семантикалық модельдің атомдық анықталған ішкі жиындары}

Мақалада кішігірім модельдердің кейбір қасиеттері, жалпы айтқанда, олар толық болу міндетті емес және олардың өзара қарым-қатынасы қарастырылған. Кішігірім модельдер деп толық теориялардың саналымды модельдерін зерттеу кезінде анықталған саналымды атомдық және жай модельдер ұғымдарының кейбір модификацияларын айтамыз. Зерттеулер Р. Вооттың саналымды жай модельдердің толық теориялары туралы классикалық нәтижесі бойынша, бірақ басқа техникалық құралдар қолдануымен жүргізілді. Бұл мақала кейбір йонсондық теорияның семантикалық моделінің арнайы ішкі жиындарының синтаксистік қасиеттеріне бағытталған. Йонсон теориясының шеңберінде атомдық тұжырымдаманы нақтылауға байланысты нәтижелер алу үшін модельдік-теориялық «реостат» ретінде жаңа тұжырым енгізілді. Осылайша, бұл мақаланың негізгі мақсаты - осы «реостатты» формалды түрде анықтау және осы ұғымның негізінде йонсондық теориялар аясында атомдық ұғымды нақтылауға түсініктемесі бар нәтижелерді алу.

Kiлm сөздер: йонсондық теория, семантикалық модель, экзистенциалды жай модель, атомдық модель, дөңестілік.

\author{
А.Р. Ешкеев, А.К. Исаева, Н.М. Мусина
}

\section{Атомные определимые подмножества семантической модели}

\begin{abstract}
В статье были рассмотрены некоторые свойства малых моделей, вообще говоря, необязательно полных теорий и их связь между собой. Под малыми моделями будем понимать некоторые модификации понятий счетных атомных и простых моделей, определенных при изучении счетных моделей полных теорий. Исследования проводились по аналогии с классическим результатом Р. Воота о счетно-простых моделях полных теорий, но другими техническими средствами. Данная работа ориентирована на синтаксические свойства специальных подмножеств семантической модели некоторой йонсоновской теории. Также было введено новое понятие - как теоретико-модельный «реостат», с целью получить результаты, имеющие отношение к уточнению понятия атомности в рамках йонсоновских теорий. Таким образом, основная цель данной статьи - формально определить данный «реостат» и получить на основе данного понятия результаты, имеющие отношение к уточнению понятия атомности в рамках йонсоновских теорий.
\end{abstract}

Ключевые слова: йонсоновская теория, семантическая модель, экзистенциально простая модель, атомная модель, выпуклость. 


\section{References}

1 Vaught, R. (1961). Denumerable models of complete theories in Infinitistic Methode. Pergamon. London. 2 Baldwin, J.T., \& Kueker, D.W. (1981). Algebraically prime models. Ann. Math. Logic., 20, $289-330$.

3 Yeshkeyev, A.R. (2015). Strongly minimal Jonsson sets and their properties. Bulletin of the Karaganda University. Mathematics series, Vol. 80, 4, 47-51.

4 Poizat, B., \& Yeshkeyev, A.R.(2018). Positive Jonsson Theories. Logica Universalis, Vol. 12, 1-2, $101-127$.

5 Yeshkeyev, A.R., \& Kasymetova, M.T. (2015). Properties of lattices of the existential formulas of Jonsson fragments. Bulletin of the Karaganda University. Mathematics series, Vol. 79, 3, 25-32.

6 Yeshkeyev, A.R., \& Ulbrikht, O.I. (2015). On lattice of existential formulas for fragment of Jonsson set. Bulletin of the Karaganda University. Mathematics series, Vol. 79, 3, 33-39.

7 Keisler, H.J., \& Chang, C.C. (1977). Teoriia modelei [Model Theory]. Moscow: Mir [in Russian].

8 Jonsson, B. (1960). Homogeneous universal relational systems. Math. Scand.

9 Yeshkeyev, A.R., \& Kasymetova, M.T. (2016). Ionsonovskie teorii i ikh klassy modelei [Jonsson theories and their classes of models]. Karaganda: Izdatelstvo KarHU [in Russian].

10 Hodges, W.A. (1993). Model Theory. Cambridge University Press.

11 Yeshkeyev, A.R., \& Issayeva, A.K. (2019). $\nabla$-cl-atomic and prime sets. Bulletin of the Karaganda University. Mathematics series, Vol. 93, 1, 88-94. 